\title{
A REVIEW OF CYCLOSPORA CAYETANENSIS TRANSPORT IN THE ENVIRONMENT
}

\author{
N. H. Onstad，M. R. Miller，M. L. Green, W. H. Witola， P. C. Davidson
}

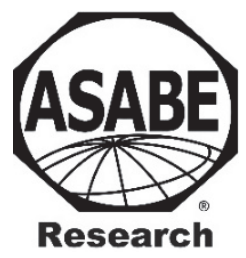

\begin{abstract}
Cyclosporiasis, a human illness marked by diarrhea, has recently emerged as a foodborne illness of concern in North America. While other reviews have focused on the epidemiology of Cyclospora cayetanensis, we focus on the environmental fate and transport of C. cayetanensis. Given the fact that cyclosporiasis is emerging in countries with advanced sanitation practices, the movement of oocysts through the environment is an important facet of the pathogen. Relatively little is known about C. cayetanensis, as it is difficult to source in developed countries, and there is no known method to culture the protozoan in the lab. This review looks at the characteristics of Cyclospora that allow it to survive in the environment and the effects of C. cayetanensis on humans.
\end{abstract}

Keywords. Cyclospora cayetanensis, Emerging pathogen, Oocyst, Environmental fate and transport, Contamination, Protozoa.

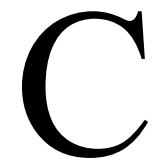

yclosporiasis, a human illness marked by diarrhea, has recently emerged as a foodborne illness of concern in North America (CDC, 2013). Cyclospora cayetanensis infection occurs via the fecaloral route. However, the oocysts are transmitted in a variety of ways, depending on the environment. In areas with minimal sanitation infrastructure, and where the pathogen is endemic, the most common source of infection is contaminated water. Agricultural fields irrigated with contaminated water or harvested produce washed with contaminated water can be sources of infective oocysts.

While other reviews have focused on the epidemiology of C. cayetanensis (Chacín-Bonilla, 2010; Fayer et al., 2000; Ortega and Sanchez, 2010; Shields and Olson, 2003), we focus on the environmental fate and transport of $C$. cayetanensis.

\section{TAXONOMY}

Cyclospora spp. are members of the phylum Apicomplexa, along with Cryptosporidium, Eimeria, Plasmodium, and Toxoplasma (Cinar et al., 2015). When the organism was

\footnotetext{
cc) $(9)$ The authors have paid for open access for this article. This work is licensed under a Creative Commons AttributionNonCommercial-NoDerivatives 4.0 International License https://creative commons.org/licenses/by-nc-nd/4.0/

Submitted for peer review in January 2019 as manuscript number NRES 13313; approved for publication as a Research Article by the Natural Resources \& Environmental Systems Community of ASABE in April 2019.

The authors are Nora H. Onstad, Instructor, and Matthew R. Miller, Graduate Student, Department of Agricultural and Biological Engineering, University of Illinois at Urbana-Champaign, Urbana, Illinois; Michelle L. Green, Instructor, Department of Biology, University of South Florida, St. Petersburg, Florida; William H. Witola, Assistant Professor, Department of Pathobiology, and Paul C. Davidson, Assistant Professor, Department of Agricultural and Biological Engineering, University of Illinois at Urbana-Champaign, Urbana, Illinois. Corresponding author: Paul Davidson, 1304 W. Pennsylvania Ave., Urbana, IL 61801; phone: 217-3003755; e-mail: pdavidso@illinois.edu.
}

detected in humans in the 1970s, it was described as a large Cryptosporidium coccidian-like body (Ortega et al., 1994). For taxonomic classification, human Cyclospora was initially proposed as a new Eimeria species (Pieniazek and Herwaldt, 1997). Despite similarities to Eimeria and other encysted protozoa, the human pathogen was added to the genus Cyclospora, which includes similar organisms that infect a variety of hosts such as snakes and primates.

Phylogenetically, Cyclospora is closest to Eimeria, given the $94 \%$ to $96 \%$ similarity in the $18 \mathrm{~S}$ rRNA sequence (Relman et al., 1996). Cinar et al. (2016) sequenced a variety of C. cayetanensis samples from around the world and found that they largely overlapped. However, additional sequencing of various geographically and temporally distinct organisms is needed in order to confidently define the genus. Eberhard et al. (1999) produced the phylogenetic tree shown in figure 1 based on the small subunit ribosomal RNA sequences.

Although genetically similar to Eimeria, Cyclospora is morphologically closer to Cryptosporidium (Fricker et al., 2002; Pieniazek and Herwaldt, 1997; Relman et al., 1996). Furthermore, both organisms exhibit similar life cycles, which include humans as a host (C. cayetanensis exclusively infects humans) and an environmental life stage (Eberhard et al., 2000; Fricker et al., 2002). Cryptosporidiosis and cyclosporiasis have similar symptoms in humans, such as diarrhea, intestinal discomfort, and nausea (Huang et al., 1995).

While morphologically similar, several major differences distinguish Cyclospora and Cryptosporidium oocysts. Cyclospora is 8 to $10 \mu \mathrm{m}$, compared to 4 to $6 \mu \mathrm{m}$ for Cryptosporidium (Li et al., 2015b; EPA, 2001). Cryptosporidium is fully mature and infective when excreted from the host, while Cyclospora requires more than a week to mature in the environment before becoming infective (Sathyanarayanan and Ortega, 2006). Additionally, Cyclospora contains two sporocysts with cell walls, whereas Cryptosporidium has 


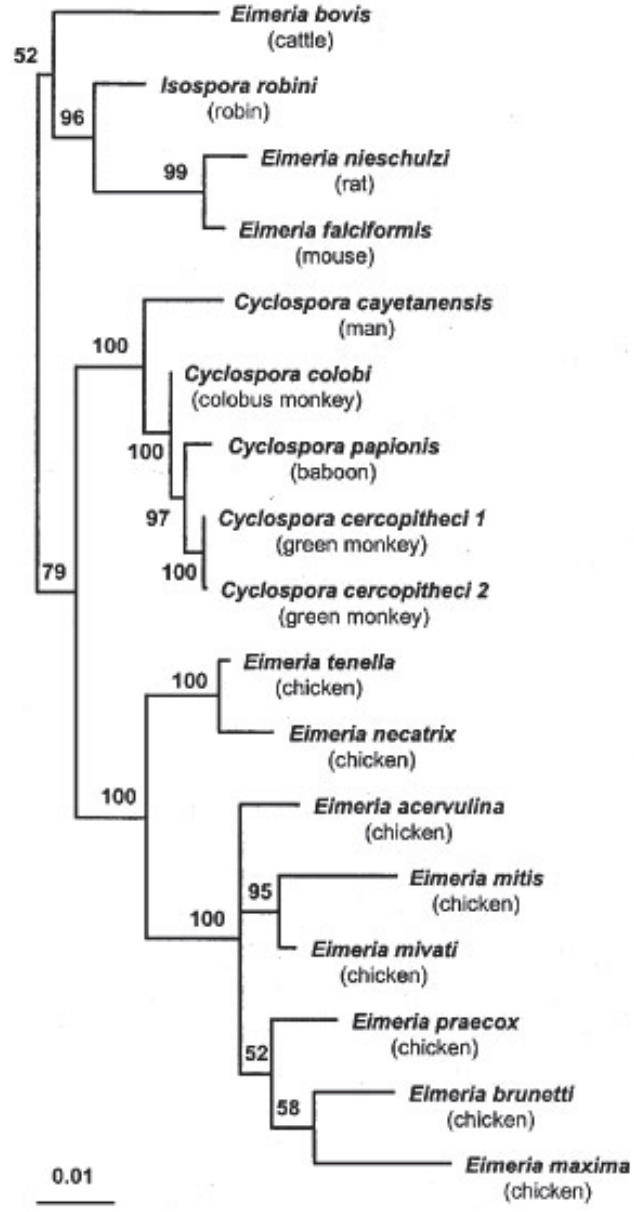

Figure 1. Phylogenetic tree of $C$. cayetanensis and related species (from Eberhard et al., 1999).

four sporozoites with no additional protective layers inside the oocyst (Eberhard et al., 1999).

\section{CYCLOSPORA SPECIES}

Nineteen species of Cyclospora have been identified to date. They infect organisms from the Diplopoda, Reptilia, and Insectivora classes as well as the Rodentia and Primate orders of Mammalia. Table 1 provides an overview of the species of Cyclospora that infect each host or hosts. These are considered the main hosts; however, there have been cases of DNA from one species of Cyclospora found in a non-traditional host (see the Host Specificity section).

\section{Host SPECIFICITY}

Several studies have found infrequent infections of $C y$ clospora spp. outside the main host species. Cyclospora spp. were detected in non-host primates in the wild and in captivity (Li et al., 2015b; Marangi et al., 2015) and in shellfish (Aksoy et al., 2014). However, the majority of infections have been detected within the primary host species. Humans have not been found to be infected with any other Cyclospora spp.; therefore, this review will focus on $C$. cayetanensis.

\section{VARIABILITY WITHIN $C$. CAYETANENSIS}

The 18S rRNA and heat shock protein (HSP70) genes were highly similar across geographically distant $C$. cayetanensis isolates from Peru, Mexico, and Nepal (Sulaiman et al., 2014), suggesting that the sampled populations have not significantly diverged into discrete populations. The $18 \mathrm{~S}$ rRNA gene in $C$. cayetanensis is very similar to that of Eimeria spp. Primers used to target the 18S rRNA gene (Relman et al., 1996) also detect Eimeria spp., so care must be taken to distinguish the organisms with another method. Further analysis of the detected DNA, through sequencing or single-nucleotide polymorphisms analysis, is required to definitively identify Cyclospora.

The internal transcribed tracer (ITS) genes have some conserved and non-conserved regions. Olivier et al. (2001) evaluated geographically variable $C$. cayetanensis samples and identified a portion of the gene that could be targeted with polymerase chain reaction (PCR) to distinguish C. cayetanensis from other Cyclospora spp. Although the $18 \mathrm{~S}$ rRNA gene has been studied more than other regions as a target for PCR, it is not as specific as the other regions. The ATCC Cyclospora cayetanensis also contains the genes for ITS- 1 and ITS-2. The two regions are located near the $18 \mathrm{~S}$ rRNA gene and provide another location for molecular detection of C. cayetanensis (Olivier et al., 2001). The portions of ITS-1 that varied were not correlated with geography.

Table 1. Cyclospora species and their host organisms.

\begin{tabular}{|c|c|c|}
\hline Cyclospora species & Hosts & Study \\
\hline C. anglomurinensis & Hispid pocket mouse (Chaetodipus hispidus) & Ford et al., 1990 \\
\hline C. ashtabulensis & Hairy-tailed mole (Parascalops breweri) & Ford and Duszynski, 1989 \\
\hline C. babaulti & Common European viper (Vipera berus) & Phisalix, 1924a \\
\hline C. caryolytica & European mole (Talpa europaea), Japanese mole (Mogera wogura coreana) & Schaudinn, 1902 \\
\hline C. cayetanensis & Human (Homo sapiens) & Ortega et al., 1994 \\
\hline C. cercopitheci & Grivet (Cercopithecus aethiops) & Eberhard et al., 1999 \\
\hline C. colobi & Mantled guereza (Colobus guereza) & Eberhard et al., 1999 \\
\hline C. glomericola & Pill millipede (Glomeris spp.) & Schneider, 1881 \\
\hline C. macacae & Rhesus macaque (Macaca mulatta) & Li et al., $2015 b$ \\
\hline C. megacephali & Eastern mole (Scalopus aquaticus) & Ford and Duszynski, 1988 \\
\hline C. niniae & Redback coffee snake (Ninia sebae sebae) & Lainson, 1965 \\
\hline C. parascalopi & Hairy-tailed mole (Parascalops breweri) & Ford and Duszynski, 1989 \\
\hline C.papionis & Olive baboon (Papio anubis) & Eberhard et al., 1999 \\
\hline C. scinci & Sandfish skink (Scincus officinalis) & Phisalix, 1924b \\
\hline C. schneideri & American pipe snake (Anilius scytale scytale) & Lainson, 2005 \\
\hline C. talpae & European mole (Talpa europaea) & Pellérdy and Tanyi, 1968 \\
\hline C. tropidonoti & Grass snake (Natrix natrix), Striped keelback snake (Natrix stolata) & Phisalix, 1924c \\
\hline C. viperae & $\begin{array}{l}\text { Ladder snake (Coluber scalaris), Colubrid snake (Coronella austriaca), } \\
\text { Viperine snake (Natrix viperinus), Asp viper (Vipera aspis) }\end{array}$ & Phisalix, 1923 \\
\hline C. zamenis & Green whip snake (Coluber viridiflavus viridiflavus) & Phisalix, 1924d \\
\hline
\end{tabular}


Olivier et al. (2001) suggested that the observed variations support the idea of polyparasitism, meaning multiple strains of $C$. cayetanensis can co-infect a host.

The heat shock protein (HSP70) gene is one of the more recent genes to be identified and sequenced to the level required for PCR. Sulaiman et al. (2013) noted that HSP70 was the same across the 16 isolates used in the study. It was also found in other apicomplexan species, but with enough genetic variation to differentiate $C$. cayetanensis.

Nuclear and mitochondrial draft genomes of C. cayetanensis are now available (Qvarnstrom et al., 2015; Guo et al., 2016; Cinar et al., 2015), leading to initial genomic investigations, including MLST analysis (Guo et al., 2016; Hofstetter et al., 2019; Li et al., 2015a). Using genome information and MLST analysis, Guo et al. (2016) found variations among $C$. cayetanensis strains recovered from China, Nepal, Indonesia, Guatemala, Peru, Spain, and the U.S. They found that strains from China grouped well together, whereas types from the U.S. also grouped well together along with types from Peru. Although the strains tended to group together, the level of diversity among them presents a challenge when attempting to determine the source or lineage of a given sample from infected individuals. The discriminatory power of the current MLST markers is limited in that strain sequences align well with outbreaks in some but certainly not all cases (Hofstetter et al., 2019). Current limitations of the methods are tied to the fact that amplification success rates are low for many samples, suggesting a need for primer optimization or re-design (Hofstetter et al., 2019). Mitochondrial DNA has been used to trace back infection sources of other parasites (e.g., Plasmodium falciparum; Conway, 2003, 2007; Preston, 2014). Although a draft of the mitochondrial genome indicates that it is approximately $6.3 \mathrm{~kb}$ in length (Cinar et al., 2015), a trace-back tool has not yet been developed for $C$. cayetanensis.

\section{LIFE CYCLE}

C. cayetanensis requires time in the environment to mature before it becomes infective. While other coccidian parasites are infectious upon being excreted, $C$. cayetanensis is excreted as an unsporulated oocyst. It requires at least seven days to begin sporulation and become infective (Sathyanarayanan and Ortega, 2006; CDC, 2013).

\section{RESILIENCY}

In the environment, Cyclospora survives inside oocysts, which are hard, shell-like structures that provide protection against environmental conditions, such as varying temperatures and $\mathrm{pH}$, as well as against chemicals and disinfectants. Other coccidian human pathogens, such as Cryptosporidium spp. and Isospora spp., also exhibit typical oocyst resilience to natural decay in the environment and disinfection processes (EPA, 2001).

Because C. cayetanensis has never been cultured or propagated in an animal model, the current best indicator for infectivity or viability is the ability of oocysts to sporulate. Many studies have used the percent sporulation to indicate whether the organism is inactivated. C. cayetanensis can survive in water for two months at $4{ }^{\circ} \mathrm{C}$ and for seven days at $37^{\circ} \mathrm{C}$ (Sathyanarayanan and Ortega, 2006). Few Cyclospora oocysts sporulated at $50^{\circ} \mathrm{C}$ (Sathyanarayanan and Ortega, 2006). However, extreme temperatures can affect the viability and sporulation time of C. cayetanensis oocysts. Cyclospora spp. oocysts optimally sporulate between $22^{\circ} \mathrm{C}$ and $30^{\circ} \mathrm{C}$ in deionized water (Smith et al., 1997). Freezing temperatures $\left(-20^{\circ} \mathrm{C}\right)$ severely limit oocyst sporulation in deionized water and other biological materials, such as milk products and leafy greens (Sathyanarayanan and Ortega, 2006). Oocysts can also be rendered inactive at freezing temperatures. Temperatures of $-20^{\circ} \mathrm{C}$ for two days or $-70^{\circ} \mathrm{C}$ for an hour will inactivate Cyclospora oocysts (Ortega and Sanchez, 2010) based on the assumption that a reduction in sporulation indicates inactivation.

Compared to other coccidian human pathogens, chemicals have limited effect on inactivation of $C$. cayetanensis. Cyclospora is resistant to the methods commonly used in water treatment, such as chlorination and chlorine dioxide $\left(\mathrm{ClO}_{2}\right)$ gas (Ortega et al., 2008). Ortega et al. (2008) inoculated basil and lettuce with $C$. cayetanensis and applied gaseous chlorine dioxide at $4.1 \mathrm{mg} \mathrm{L}^{-1}$ for $20 \mathrm{~min}$ but noted no change in sporulation at this treatment level. Hydrogen peroxide is used to inactivate Cryptosporidium; however, studies tend to evaluate chemical disinfectants on other, easier to study protozoa (Ortega, 2008). Therefore, little is known about the effects of chemical disinfectants on Cyclospora.

Pesticides appear to have inconsequential effects on C. cayetanensis. Sathyanarayanan and Ortega (2004) tested three fungicides (captan 50\% W.P., benomyl 50\% W.P., and zineb $75 \%$ W.P.) and two insecticides (malathion 25\% W.P. and diazinon $4 \mathrm{E} 47.5 \%$ ) at varying concentrations (below, at, and above recommended concentration levels for those pesticides). The effects of those treatments were evaluated at intervals between $30 \mathrm{~min}$ and one week. There was no change in sporulation up to $24 \mathrm{~h}$, but the sporulation percentage was reduced with benomyl after one week of exposure (Sathyanarayanan and Ortega, 2004).

Ultraviolet radiation has the potential to inactivate $C$. cayetanensis. Broiler chickens fed Eimeria acervulina (as a surrogate for $C$. cayetanensis) oocysts from UV-treated raspberries and basil had a lower rate of infection than those fed untreated foods (Kniel et al., 2007).

Various other methods, such as desiccation and highpressure processing, have been suggested as methods for reducing the risk of cyclosporiasis infection. A coccidian organism thought to be Cyclospora was extremely sensitive to rupture when subjected to desiccation (Long et al., 1991). However, the identification of the organism was not confirmed. High-pressure processing $\left(550 \mathrm{MPa}\right.$ at $40^{\circ} \mathrm{C}$ for $2 \mathrm{~min}$ ), a common food sterilization method, was used to treat E. acervulina oocyst-infected raspberries. The raspberries were fed to broiler chickens, but the birds remained asymptomatic and did not shed oocysts (Kniel et al., 2007). It is unclear how these findings transfer to $C$. cayetanensis.

\section{HUMAN INFECTION}

Cyclosporiasis is a particular risk for young, elderly, and immunocompromised individuals. Infection is thought to occur with ingestion of as few as 10 to 100 oocysts. The number 
of cases of cyclosporiasis increased in 2018 from the previous years. As of October 4, 2017, 1,065 cases were reported to the Centers for Disease Control and Prevention (CDC) from the summer of 2017 alone (CDC, 2017). In 2018, 2,299 cases were reported to the CDC as of October 1, 2018. This dramatic increase in cases in 2018 was attributed to an increase in the number of separate outbreaks and the use of new diagnostic techniques, such as multiplex polymerase chain reaction (PCR), to correctly diagnose cases that may not have been identified in previous years $(\mathrm{CDC}$, 2018a).

\section{TREATMENT FOR CYCLOSPORIASIS}

While cyclosporiasis often resolves itself given time, treatments are available. Dehydration is a concern with extended periods of diarrhea, so it is important to ensure that infected individuals remain hydrated. Often individuals without additional health concerns resolve the infection on their own. When treatment is required, trimethoprim/sulfamethoxazole (TMP/SMX) is the only drug combination available (CDC, 2013). There is no alternative treatment for individuals for whom TMP/SMX does not work, typically due to a sulfa allergy or because they did not respond to the treatment. HIVpositive and other immuno-compromised individuals are generally treated with TMP/SMX to minimize complications.

As with many intestinal parasites, such as Giardia and Cryptosporidium, patients are often provided treatment before the infection is identified. However, cyclosporiasis does not respond to any treatments that work for other intestinal parasites, and TMP/SMX does not treat other common protozoan infections. The difficulties associated with diagnosing the illness and successfully treating the individual can lead to longer infections compared to other parasitic diseases.

\section{FOOD SAFETY AND DETECTION}

Currently, there is no way to identify Cyclospora-contaminated food as it is transported (Buss et al., 2015). Existing detection techniques involve destroying the food to concentrate the oocysts. However, the U.S. Food and Drug Administration recently validated real-time PCR (rt-PCR) methods designed to detect $C$. cayetanensis on food items including leafy greens (e.g., cilantro, lettuces, basil), soft fruit (e.g., strawberries, blackberries, raspberries), and whole vegetables (e.g., beans and peas). Cilantro, parsley, and shredded carrots are also covered by the newly validated methods (FDA, 2017). More research needs to be done to develop methods for detecting Cyclospora and then inactivating or destroying the oocysts on intact food.

\section{Environmental Prevalence GEOGRAPHIC DISTRIBUTION}

Cyclospora cayetanensis is found throughout the world. Most endemic countries are located in tropical or semi-tropical regions. The U.S. is considered to have no endemic $C y$ clospora (CDC, 2013). Numerous infections of cyclosporiasis occur each year in non-endemic areas due to travel and foodborne transmission from imported food (CDC, 2013).

Cyclosporiasis is markedly seasonal, with the majority of cases occurring during spring to autumn. In the U.S. and much of Europe, imported produce in the summer months may cause outbreaks, but with waste treatment facilities that can remove oocysts, reinfection from the environment is not such a concern. Some older sewage systems have combined sewage overflows (CSOs) that discharge untreated sewage into streams during high rainfall events. These CSOs may introduce human pathogens such as $C$. cayetanensis into the environment, making it difficult to prevent such pathogens from becoming endemic if the climate allows year-round survival. It is difficult to identify areas that are endemic because of the challenges associated with sampling and testing a variety of potentially contaminated soils, water sources, and foods.

\section{TRANSMISSION IN THE ENVIRONMENT}

In developed regions with advanced sanitation practices, cases of cyclosporiasis have largely been caused by contaminated produce and berries imported from endemic areas (Baldursson and Karanis, 2011; CDC, 2018a, 2018b; ChacinBonilla, 2017; Herwaldt, 2016). In these regions, human waste rarely comes into contact with the environment, so the life cycle of Cyclospora is inhibited by the inability to mature in the environment and then infect another host. However, some recent studies have found $C$. cayetanensis in developed areas (Galván et al., 2012; Giangaspero et al., 2015; Kitajima et al., 2014). Among known causes, Figure 2 illus-trates the various ways oocysts can be transferred from different sources in the environment.

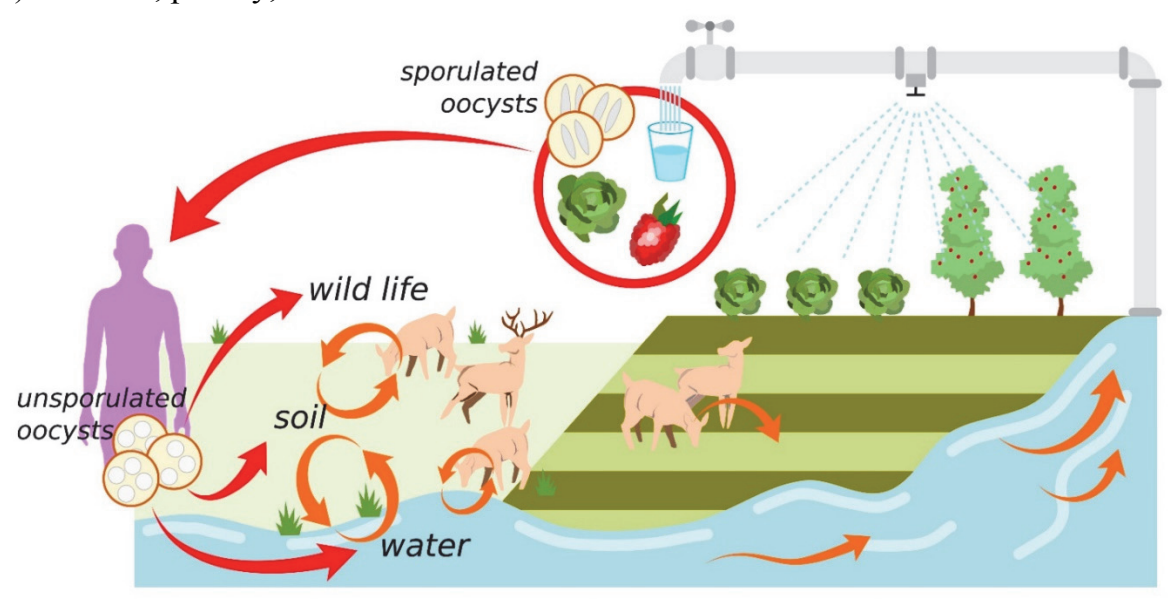

Figure 2. Potential routes of $C$. cayetanensis transport in the environment. 


\section{Wildlife}

Studies have not yet identified domestic or wild animals as the source of infection in humans, although contact with animals has been associated with infection (Marangi et al., 2015). C. cayetanensis has been found in shellfish (Aksoy et al., 2014). Several fecal samples from animals in Nepal tested positive for $C$. cayetanensis (Chu et al., 2004). Fecal samples from two dogs, a monkey, and a chicken tested positive for $C$. cayetanensis through both genetic and microscopic analyses, but infection was not confirmed because tissues were not available for examination. From these studies, it is unclear whether animals could be infected by $C$. cayetanensis or if they could transport oocysts in the environment.

\section{Soil}

Contact with soil contaminated with feces was found to be associated with infection on San Carlos Island, Venezuela (Chacín-Bonilla et al., 2007). The authors suggested that ingesting soil may be a factor for infection. A review paper on soil transmission of Cyclospora was written by ChacínBonilla (2008). Contaminated soil was also detected in Italy, but transmission methods were unclear (Giangaspero et al., 2015).

Soil type can affect transmission of Cryptosporidium oocysts through the soil matrix. For instance, Davidson et al. (2014) and Mawdsley et al. (1996) found that recovery of C. parvum oocysts was higher for clayey soils than sandy soils, likely due to the decreased infiltration rate of the clayey soils. However, analyses of soil cores by Davidson et al. (2014) showed that oocysts bound more tightly to clay particles than sand particles, which is in agreement with the findings of McLaughlin et al. (2013) and Kuczynska and Shelton (1999). Due to the similarity between Cryptosporidium and Cyclospora, this may be an important aspect of environmental transport and should be a focus of future work. Unfortunately, transmission of $C$. cayetanensis oocysts by contaminated soil is still not well understood. Further studies to identify risk factors and specific modes of transmission are necessary to understand the risk of infection due to soil.

\section{Water}

Most water treatment processes rely on a variety of biological, chemical, and physical methods. Cyclospora oocysts are large, relative to most waterborne pathogens, and therefore are easier to remove by physical methods (i.e., sand filtration) compared to chemical methods (Ortega et al., 2008). Chlorination is a common water treatment method, but it does not inactivate Cyclospora oocysts. Cyclospora oocysts are very robust and can remain active even with chlorine disinfection (Kitajima et al., 2014). Physical treatment methods appear to be most effective because the oocysts are relatively large. Sedimentation and flocculation can help remove oocysts in settling tanks. When standard treatment methods are not present, or are not working properly due to inadequate maintenance, oocysts may pass through the treatment process and back into surface water systems. Once in the surface water, oocysts can be transported long distances and reintroduced onto crops by processes such as irrigation, when water is sprayed onto the crops or applied using furrow or flood irrigation, dispersing oocysts to a wide area.
In regions with improved sanitation and wastewater management systems, water treatment is normally sufficient to remove Cyclospora oocysts. This makes it difficult for oocysts to enter a water supply in high quantities. Nevertheless, a study in Spain sampled several drinking water and wastewater treatment plants (both upstream and downstream) and locations of interest along a river over a oneyear period from 2008-2009 (Galván et al., 2012). Out of 223 samples, 9\% (20 samples) contained Cyclospora spp., and $C$. cayetanensis was found in 17 of those 20 samples. For the majority of the seasons, the raw influent contained fewer positive samples than the treated effluent. However, there were more positive treated samples than raw samples in spring in the wastewater treatment plants. The authors concluded that existing regulations for water treatment are insufficient to protect the public from $C$. cayetanensis because there are no regulations for managing $C$. cayetanensis in drinking water or wastewater.

A study of two wastewater treatment plants in Arizona found $C$. cayetanensis in both the influent and effluent (Kitajima et al, 2014). Nine of the 48 samples collected from 2011-2012 were positive for $C$. cayetanensis using a novel qPCR technique; however, the authors did not determine the removal efficiency of the wastewater treatment plants.

\section{Food}

Foods that are eaten raw can be contaminated by contact with contaminated water or human waste. The major hurdle in managing the spread of Cyclospora is the inability to detect contaminated produce in the supply chain and remove the pathogen once it is detected. There is still much that is not known about how $C$. cayetanensis adheres to foods, how long it persists, and how to minimize the risk to humans.

While many outbreaks of cyclosporiasis are never traced to a specific source, some outbreaks are attributed to contaminated imported produce and berries (Baldursson and Karanis, 2011; Buss et al., 2015; Hall et al., 2012; Herwaldt and Ackers, 1997; Piche et al., 2002). There have been many reported outbreaks of cyclosporiasis in North America (Abanyie et al., 2015; Hall et al., 2012; Kozak et al., 2013). The outbreak in summer 2017 included a reported 1,065 individuals, many of whom likely became infected domestically due to contaminated foods (CDC, 2017). A jump in cases in summer 2018, to 2,299 confirmed cases, was attributed to improved testing using the new FDA methods (Almeria et al., 2018; Murphy et al., 2018; Murphy and Lee, 2017) to identify more cases than in the past (CDC, 2018a). Any produce imported from regions with endemic $C$. cayetanensis is a potential source for domestic outbreaks of cyclosporiasis in the U.S.

\section{Conclusions}

Cyclospora cayetanensis is an emerging pathogen of concern, but little is known about how it is transported. Fieldscale contamination is a major concern, as $C$. cayetanensis requires time in the environment to mature before becoming infective. Water, soil, and animals have been found to carry oocysts, and all can transfer oocysts to crops grown on contaminated fields. When the produce is harvested and sent to 
non-endemic regions, the oocysts may cause cyclosporiasis. Soil and wildlife are the least understood modes of transmission. More research is needed to understand the complete life cycle of $C$. cayetanensis in the environment, as well as to improve food safety and prevent outbreaks.

Future research efforts should focus on increasing our understanding of the fate and transport of Cyclospora oocysts through soil and water, developing better molecular detection methods for $C$. cayetanensis and trace-back applications, and assessing the risk of wildlife as a transport vector. The combined effect of wildlife transporting oocysts, in the absence of soil or water, coupled with the transport of oocysts in soil or water makes for a complex transport cycle. Our understanding of such a complex cycle is critical for designing and recommending best management practices for oocyst removal. The effects of climate change, which could lengthen the season when Cyclospora infections peak, should also be considered when developing risk assessment plans.

\section{REFERENCES}

Abanyie, F., Harvey, R. R., Harris, J. R., Wiegand, R. E., \& Gaul, L. (2015). 2013 multistate outbreaks of Cyclospora cayetanensis infections associated with fresh produce: Focus on the Texas investigations. Epidemiol. Infect., 143(16), 3451-3458. https://doi.org/10.1017/S0950268815000370

Aksoy, U., Marangi, M., Papini, R., Ozkoc, S., Bayram Delibas, S., \& Giangaspero, A. (2014). Detection of Toxoplasma gondii and Cyclospora cayetanensis in Mytilus galloprovincialis from Izmir Province coast (Turkey) by real-time PCR/high-resolution melting analysis (HRM). Food Microbiol., 44, 128-135. https://doi.org/10.1016/j.fm.2014.05.012

Almeria, S., da Silva, A. J., Blessington, T., Cloyd, T. C., Cinar, H. N., Durigan, M., \& Murphy, H. R. (2018). Evaluation of the U.S. Food and Drug Administration validated method for detection of Cyclospora cayetanensis in high-risk fresh produce matrices and a method modification for a prepared dish. Food Microbiol., 76, 497-503. https://doi.org/10.1016/j.fm.2018.07.013

Baldursson, S., \& Karanis, P. (2011). Waterborne transmission of protozoan parasites: Review of worldwide outbreaks: An update 2004-2010. Water Res., 45(20), 6603-6614. https://doi.org/10.1016/j.watres.2011.10.013

Buss, B. F., Joshi, M. V., O'Keefe, A. L., Allensworth, C. D., Garvey, A., Obbink, K., ... Safranek, T. J. (2015). Regional investigation of a cyclosporiasis outbreak linked to imported romaine lettuce: Nebraska and Iowa, June-August 2013. Epidemiol. Infect., 144(9), 1807-1817. https://doi.org/10.1017/S0950268815002484

CDC. (2013). Cyclosporiasis (Cyclospora infection): Surveillance and outbreak response. Atlanta, GA: Centers for Disease Control and Prevention. Retrieved from https://www.cdc.gov/parasites/cyclosporiasis/surveillance.html

CDC. (2017). Cyclosporiasis outbreak investigations: United States, 2017. Atanta, GA: Centers for Disease Control and Prevention. Retrieved from https://www.cdc.gov/parasites/cyclosporiasis/outbreaks/2017/in dex.html

CDC. (2018a). Domestically acquired cases of cyclosporiasis: United States, May-August 2018. Atlanta, GA: Centers for Disease Control and Prevention. Retrieved from https://www.cdc.gov/parasites/cyclosporiasis/outbreaks/2018/c- 082318/index.html

CDC. (2018b). Multistate outbreak of cyclosporiasis linked to Del Monte fresh produce vegetable trays: United States, 2018. Atlanta, GA: Centers for Disease Control and Prevention. Retrieved from https://www.cdc.gov/parasites/cyclosporiasis/outbreaks/2018/a062018/index.html

Chacin-Bonilla, L. (2008). Transmission of Cyclospora cayetanensis infection: A review focusing on soil-borne cyclosporiasis. Trans. Royal Soc. Trop. Med. Hygiene, 102(3), 215-216. https://doi.org/10.1016/j.trstmh.2007.06.005

Chacin-Bonilla, L. (2010). Epidemiology of Cyclospora cayetanensis: A review focusing in endemic areas. Acta Trop., 115(3), 181-193.

https://doi.org/10.1016/j.actatropica.2010.04.001

Chacin-Bonilla, L. (2017). Cyclospora cayetanensis. In J. B. Rose, B. Jimenez-Cisneros, R. Fayer, \& W. Jakubowski (Eds.), Global water pathogens project. East Lansing, MI: Michigan State University, UNESCO. Retrieved from http://www.waterpathogens.org/book/cyclospora-cayetanensis

Chacin-Bonilla, L., Barrios, F., \& Sanchez, Y. (2007). Epidemiology of Cyclospora cayetanensis infection in San Carlos Island, Venezuela: Strong association between socioeconomic status and infection. Trans. Royal Soc. Trop. Med. Hygiene, 101(10), 1018-1024. https://doi.org/10.1016/j.trstmh.2007.05.008

Chu, D.-M. T., Sherchand, J. B., Cross, J. H., \& Orlandi, P. A. (2004). Detection of Cyclospora cayetanensis in animal fecal isolates from Nepal using an FTA filter-base polymerase chain reaction method. American J. Trop. Med. Hygiene, 71(4), 373379. https://doi.org/10.4269/ajtmh.2004.71.373

Cinar, H. N., Gopinath, G., Jarvis, K., \& Murphy, H. R. (2015). The complete mitochondrial genome of the foodborne parasitic pathogen Cyclospora cayetanensis. PLoS One, 10(6), e0128645. https://doi.org/10.1371/journal.pone.0128645

Cinar, H. N., Qvarnstrom, Y., Wei-Pridgeon, Y., Li, W., Nascimento, F. S., Arrowood, M. J., ... Gopinath, G. R. (2016). Comparative sequence analysis of Cyclospora cayetanensis apicoplast genomes originating from diverse geographical regions. Parasites Vectors, 9(1), 1-14. https://doi.org/10.1186/s13071-016-1896-4

Conway, D. J. (2003). Tracing the dawn of Plasmodium falciparum with mitochondrial genome sequences. Trends Genetics, 19(12), 671-674. https://doi.org/10.1016/j.tig.2003.10.007

Conway, D. J. (2007). Molecular epidemiology of malaria. Clin. Microbiol. Rev., 20(1), 188-204. https://doi.org/10.1128/cmr.00021-06

Davidson, P. C., Kuhlenschmidt, T. B., Bhattarai, R., Kalita, P. K., $\&$ Kuhlenschmidt, M. S. (2014). Effects of soil type and cover condition on Cryptosporidium parvum transport in overland flow. Water Air Soil Pollut., 225(3). https://doi.org/10.1007/s11270-014-1882-4

Eberhard, M. L., da Silva, A. J., Lilley, B. G., \& Pieniazek, N. J. (1999). Morphologic and molecular characterization of new Cyclospora species from Ethiopian monkeys: C. cercopitheci sp.n., C. colobi sp.n., and C. papionis sp.n. Emerg. Infect. Dis. J., 5(5), 651-658. https://doi.org/10.3201/eid0505.990506

Eberhard, M. L., Ortega, Y. R., Hanes, D. E., Nace, E. K., Do, R. Q., Robl, M. G., ... Arrowood, M. J. (2000). Attempts to establish experimental Cyclospora cayetanensis infection in laboratory animals. J. Parasitol., 86(3), 577-582. https://doi.org/10.2307/3284875

EPA. (2001). Cryptosporidium: Drinking water health advisory. Washington, DC: U.S. Environmental Protection Agency. Retrieved from https://www.epa.gov/sites/production/files/201510/documents/cryptosporidium-report.pdf 
Fayer, R., Morgan, U., \& Upton, S. J. (2000). Epidemiology of Cryptosporidium: Transmission, detection, and identification. Intl. J. Parasitol., 30(12), 1305-1322. https://doi.org/10.1016/S0020-7519(00)00135-1

FDA. (2017). BAM 19b: Molecular detection of Cyclospora cayetanensis in fresh produce using real-time PCR. Washington, DC: U.S. Food and Drug Administration. Retrieved from https://www.fda.gov/food/foodscienceresearch/laboratorymetho ds/ucm553445.htm

Ford, P. L., \& Duszynski, D. W. (1988). Coccidian parasites from insectivores: VI. Six new species from the eastern mole, Scalopus aquaticus. J. Protozool., 35(2), 223-226. https://doi.org/10.1111/j.1550-7408.1988.tb04328.x

Ford, P. L., \& Duszynski, D. W. (1989). Coccidian parasites (Apicomplexa: Eimeriidae) from insectivores: VII. Six new species from the hairy-tailed mole, Parascalops breweri. J. Parasitol., 75(4), 508-513. https://doi.org/10.2307/3282897

Ford, P. L., Duszynski, D. W., \& McAllister, C. T. (1990). Coccidia (Apicomplexa) from heteromyid rodents in the southwestern United States, Baja California, and northern Mexico with three new species from Chaetodipus hispidus. J. Parasitol., 76(3), 325-331. https://doi.org/10.2307/3282659

Fricker, C. R., Medema, G. D., \& Smith, V. (2002). Protozoan parasites (Cryptosporidium, Giardia, Cyclospora). In Guidelines for drinking-water quality. Addendum microbiological agents in drinking water (2nd ed., pp. 70-118). Geneva, Switzerland: World Health Organization.

Galván, A. L., Magnet, A., Izquierdo, F., Fenoy, S., Rueda, C., Fernandez Vadillo, C., ... del Aguila, C. (2013). Molecular characterization of human-pathogenic microsporidia and Cyclospora cayetanensis isolated from various water sources in Spain: A year-long longitudinal study. Appl. Environ. Microbiol., 79(2), 449-459. https://doi.org/10.1128/aem.0273712

Giangaspero, A., Marangi, M., Koehler, A. V., Papini, R., Normanno, G., Lacasella, V., ... Gasser, R. B. (2015). Molecular detection of Cyclospora in water, soil, vegetables, and humans in southern Italy signals a need for improved monitoring by health authorities. Intl. J. Food Microbiol., 211, 95-100. https://doi.org/10.1016/j.ijfoodmicro.2015.07.002

Guo, Y., Roellig, D. M., Li, N., Tang, K., Frace, M., Ortega, Y. R., ... Xiao, L. (2016). Multilocus sequence typing tool for Cyclospora cayetanensis. Emerg. Infect. Dis. J., 22(8), 14641467. https://doi.org/10.3201/eid2208.150696

Hall, R. L., Jones, J. L., Hurd, S., Smith, G., Mahon, B. E., \& Herwaldt, B. L. (2012). Population-based active surveillance for Cyclospora infection: United States, foodborne diseases active surveillance network (FoodNet), 1997-2009. Clin. Infect. Dis., 54(S5), 411-417. https://doi.org/10.1093/cid/cis049

Herwaldt, B. L. (2016). Cyclospora cayetanensis: A review, focusing on the outbreaks of cyclosporiasis in the 1990s. Clin. Infect. Dis., 31(4), 1040-1057. https://doi.org/10.1086/314051

Herwaldt, B. L., \& Ackers, M.-L. (1997). An outbreak in 1996 of cyclosporiasis associated with imported raspberries. New England J. Med., 336(22), 1548-1556.

https://doi.org/10.1056/nejm199705293362202

Hofstetter, J. N., Nascimento, F. S., Park, S., Casillas, S., Herwaldt, B. L., Arrowood, M. J., \& Qvarnstrom, Y. (2019). Evaluation of multilocus sequence typing of Cyclospora cayetanensis based on microsatellite markers. Parasite, 26, article 3. http://doi.org/10.1051/parasite/2019004

Huang, P., Weber, J. T., Sosin, D. M., Griffin, P. M., Long, E. G., Murphy, J. J., ... Kallick, C. (1995). The first reported outbreak of diarrheal illness associated with Cyclospora in the United States. Ann. Internal Med., 123(6), 409-414.

Kitajima, M., Haramoto, E., Iker, B. C., \& Gerba, C. P. (2014).
Occurrence of Cryptosporidium, Giardia, and Cyclospora in influent and effluent water at wastewater treatment plants in Arizona. Sci. Total Environ., 484(1), 129-136. https://doi.org/10.1016/j.scitotenv.2014.03.036

Kniel, K. E., Shearer, A. E., Cascarino, J. L., Wilkins, G. C., \& Jenkins, M. C. (2007). High hydrostatic pressure and UV light treatment of produce contaminated with Eimeria acervulina as a Cyclospora cayetanensis surrogate. J. Food Prot., 70(12), 28372842. https://doi.org/10.4315/0362-028x-70.12.2837

Kozak, G. K., Macdonald, D., Landry, L., \& Farber, J. M. (2013). Foodborne outbreaks in Canada linked to produce: 2001 through 2009. J. Food Prot., 76(1), 173-183. https://doi.org/10.4315/0362-028x.jfp-12-126

Kuczynska, E., \& Shelton, D. R. (1999). Method for detection and enumeration of Cryptosporidium parvum oocysts in feces, manures, and soils. Appl. Environ. Microbiol., 65, 2820-2826.

Lainson, R. (1965). Parasitological studies in British Honduras: II. Cyclospora niniae sp.n. (Eimeriidae: Cyclosporinae) from the snake Ninia sebae sebae (Colubridae). Ann. Trop. Med. Parasitol., 59(2), 159-163.

https://doi.org/10.1080/00034983.1965.11686294

Lainson, R. (2005). The genus Cyclospora (Apicomplexa: Eimeriidae), with a description of Cyclospora schneideri n.sp. in the snake Anilius scytale scytale (Aniliidae) from Amazonian Brazil: A review. Mem. Inst. Oswaldo Cruz, 100(2), 103-110. https://doi.org/10.1590/S0074-02762005000200001

Li, J., Chang, Y., Shi, K. E., Wang, R., Fu, K., Li, S., ... Zhang, L. (2015a). Multilocus sequence typing and clonal population genetic structure of Cyclospora cayetanensis in humans. Parasitol. Res, 144(14), 1890-1897. https://doi.org/10.1017/S0031182017001299

Li, N., Ye, J., Arrowood, M. J., Ma, J., Wang, L., Xu, H., ... Xiao, L. (2015b). Identification and morphologic and molecular characterization of Cyclospora macacae $\mathrm{n}$. sp. from rhesus monkeys in China. Parasitol. Res, 114(5), 1811-1816. https://doi.org/10.1007/s00436-015-4367-5

Long, E. G., White, E. H., Carmichael, W. W., Quinlisk, P. M., Raja, R., Swisher, B. L., ... Cohen, M. T. (1991). Morphologic and staining characteristics of a cyanobacterium-like organism associated with diarrhea. J. Infect. Dis., 164(1), 199-202. https://doi.org/10.1093/infdis/164.1.199

Marangi, M., Koehler, A. V., Zanzani, S. A., Manfredi, M. T., Brianti, E., Giangaspero, A., \& Gasser, R. B. (2015). Detection of Cyclospora in captive chimpanzees and macaques by a quantitative PCR-based mutation scanning approach. Parasites Vectors, 8(1), 274. https://doi.org/10.1186/s13071-015-0872-8

Mawdsley, J. L., Brooks, A. E., \& Merry, R. J. (1996). Movement of the protozoan pathogen Cryptosporidium parvum through three contrasting soil types. Biol. Fert. Soils, 21(1-2), 30-36. https://doi.org/10.1007/BF00335990

McLaughlin, S. J., Kalita, P. K., \& Kuhlenschmidt, M. S. (2013). Fate of Cryptosporidium parvum oocysts within soil, water, and plant environment. J. Environ. Mgmt., 131, 121-128. https://doi.org/10.1016/j.jenvman.2013.09.017

Murphy, H. R., Cinar, H. N., Gopinath, G., Noe, K. E., Chatman, L. D., Miranda, N. E., ... da Silva, A. J. (2018). Interlaboratory validation of an improved method for detection of Cyclospora cayetanensis in produce using a real-time PCR assay. Food Microbiol., 69, 170-178. https://doi.org/10.1016/j.fm.2017.08.008

Murphy, H. R., \& Lee, S.(2017). Evaluation of an improved U.S. Food and Drug Administration method for the detection of Cyclospora cayetanensis in produce using real-time PCR. $J$. Food Prot., 80(7), 1133-1144. https://doi.org/10.4315/0362028x.jfp-16-492

Olivier, C., van de Pas, S., Lepp, P. W., Yoder, K., \& Relman, D. 
A. (2001). Sequence variability in the first internal transcribed spacer region within and among Cyclospora species is consistent with polyparasitism. Intl. J. Parasitol., 31(13), 1475-1487. https://doi.org/10.1016/S0020-7519(01)00283-1

Ortega, Y. R., \& Sanchez, R. (2010). Update on Cyclospora cayetanensis, a foodborne and waterborne parasite. Clin. Microbiol. Rev., 23(1), 218-234. https://doi.org/10.1128/cmr.00026-09

Ortega, Y. R., Gilman, R. H., \& Sterling, C. R. (1994). A new coccidian parasite (Apicomplexa: Eimeriidae) from humans. $J$. Parasitol., 80(4), 625-629. https://doi.org/10.2307/3283201

Ortega, Y. R., Mann, A., Torres, M. P., \& Cama, V. (2008). Efficacy of gaseous chlorine dioxide as a sanitizer against Cryptosporidium parvum, Cyclospora cayetanensis, and Encephalitozoon intestinalis on produce. J. Food Prot., 71(12), 2410-2414. https://doi.org/10.4315/0362-028x-71.12.2410

Pellérdy, L., \& Tanyi, Z. (1968). Cyclospora talpae sp.n. (Protozoa: Sporozoa) from the liver of Talpa europaea. Folia Parasitol. (Praha), 15, 275-277.

Phisalix, M. (1923). Coccidiose intestinale de la vipère aspic à Cyclospora viperae n.sp. Bull. Soc. Path. Exot., 16, 637-642.

Phisalix, M. (1924a). Coccidiose intestinale de Vipera berus a Cyclospora babaulti nov.sp. Bull. Soc. Path. Exot., 17, 868-871.

Phisalix, M. (1924b). Coccidiose intestinale du Scincus officinalis Laur., a Cyclospora scinci nov.sp. Bull. Mus. Nat. Hist. Paris, 30, 100-101.

Phisalix, M. (1924c). Cyclospora tropidonoti nov.spec., coccidie intestinale de la couleuvre a collier. Bull. Soc. Path. Exot., 17, 871-873.

Phisalix, M. (1924d). Cyclospora zamenis nov.sp., coccidie à localisation intestinale de Zamenis viridiflavus Lacép. Bull. Mus. Nat. Hist. Paris, 30, 501-502.

Piche, R., Chen, R., Hoang, L., Dixon, B., \& Cross, J. H. (2002). Molecular epidemiological studies on two cyclosporiasis outbreaks in Vancouver, British Columbia. Proc. 10th Intl. Congress of Parasitology (pp. 89-92).

Pieniazek, N. J., \& Herwaldt, B. L. (1997). Reevaluating the molecular taxonomy: Is human-associated Cyclospora a mammalian Eimeria species? Emerg. Infect. Dis., 3(3), 381-383. https://doi.org/10.3201/eid0303.970319

Preston, M. D., Campino, S., Assefa, S. A., Echeverry, D. F., Ocholla, H., Amambua-Ngwa, A., ... Clark, T. G. (2014). A barcode of organellar genome polymorphisms identifies the geographic origin of Plasmodium falciparum strains. Nature
Comm., 5, article 4052.

https://www.nature.com/articles/ncomms5052

Qvarnstrom, Y., Wei-Pridgeon, Y., Li, W, Nascimento, F. S., Bishop, H. S., Herwaldt, B. L., Moss, D. M., ... Arrowood, M. J. (2015). Draft genome sequences from Cyclospora cayetanensis oocysts purified from a human stool sample. Microbiol. Resour. Announc., 3(6), article e01324-15. https://doi.org/10.1128/genomeA.01324-15

Reiman, D. A., Schmidt, T. M., Gajadhar, A., Sogin, M., Cross, J., Yoder, K., ... Echeverria, P. (1996). Molecular phylogenetic analysis of Cyclospora, the human intestinal pathogen, suggests that it is closely related to Eimeria species. J. Infect. Dis., 173(2), 440-445. https://doi.org/10.1093/infdis/173.2.440

Sathyanarayanan, L., \& Ortega, Y. (2004). Effects of pesticides on sporulation of Cyclospora cayetanensis and viability of Cryptosporidium parvum. J. Food Prot., 67(5), 1044-1049. https://doi.org/10.4315/0362-028x-67.5.1044

Sathyanarayanan, L., \& Ortega, Y. (2006). Effects of temperature and different food matrices on Cyclospora cayetanensis oocyst sporulation. J. Parasitol., 92(2), 218-222. Retrieved from https://doi.org/10.1645/GE-630R.1

Schaudinn, F. (1902). Studien über krankheitserregende Protozoen I. Cyclospora caryolitica Shaud., der Erreger der perniciösen Enteritis des Maulwurfs. Arbeiten aus dem Kaiserlichen Gesundheitsamte, 18(8), 378-416.

Schneider, A. (1881). Sur les psorospermies oviformes ou coccidies. Espécies nouvelles ou peu connues. Arch. Zool. Exp. Gen., 9, 387-404.

Shields, J. M., \& Olson, B. H. (2003). Cyclospora cayetanensis: A review of an emerging parasitic coccidian. Intl. J. Parasitol., 33(4), 371-391. https://doi.org/10.1016/S0020-7519(02)00268-0

Smith, H. V., Paton, C. A., Mtambo, M. M. A., \& Girdwood, R. W. A. (1997). Sporulation of Cyclospora sp. oocysts. Appl. Environ. Microbiol., 63(4), 1631-1632.

Sulaiman, I. M., Ortega, Y., Simpson, S., \& Kerdahi, K. (2014). Genetic characterization of human-pathogenic Cyclospora cayetanensis parasites from three endemic regions at the $18 \mathrm{~S}$ ribosomal RNA locus. Infect. Genet. Evol., 22, 229-234. https://doi.org/10.1016/j.meegid.2013.07.015

Sulaiman, I. M., Torres, M. P., Simpson, S., Kerdahi, K., \& Ortega, Y. (2013). Sequence characterization of heat shock protein gene of Cyclospora cayetanensis isolates from Nepal, Mexico, and Peru. J. Parasitol., 99(2), 379-382. https://doi.org/10.1645/GE3114.1 